\title{
Neglected Tropical Diseases: social and environmental inequalities in the Brazilian Amazon
}

\author{
Corrêa LL*, Figueira MCS, Pinheiro ASF
}

Department of Parasitology, Institute of Water Science and Technology, Federal University of Western Pará, Ufopa, Brazil

\begin{abstract}
The present study was to Parasitic diseases are associated with the environmental dynamics of the Brazilian Amazon. In this way each Amazonian city has peculiarities that cannot be compared with other classic endemic regions. Despite advances in understanding the cycle of parasitic diseases for diagnostic and therapeutic purposes, prevention work remains a challenge. All diagnostic strategies aimed at identification and treatment are deficient in reporting, prevention and control. In this way, it is perceived that there is a need for improvements in the information networks involved in these diseases, specifically in Amazonia, so that they can be prioritized and elaborate public policies so that they do not remain neglected tropical diseases.
\end{abstract}

Keywords: Neglected Tropical Diseases, Parasitic diseases, Brazilian Amazon.

Accepted February 10, 2018

\section{Introduction}

There is limited interest in diseases considered to be neglected, or Neglected Tropical Diseases (NTD), which are considered a reflection of economic, social, ethnic and health inequalities. To broaden the identification of their characteristics of vulnerability, such illnesses are currently described as "poverty related diseases" or simply "poverty diseases" [1,2].

One example of a vulnerable population with these characteristics is the rural population of Brazil. This group lives in conditions of total socioeconomic inequality, caused by a number of difficulties, among them unsuitable and insufficient sewage and water supply systems [3,4]. To tackle these problems, Brazil has created the Política Nacional de Saúde

Integral das Populações do Campo e da Floresta (the National Integral Health Policy for Field and Forest Populations) (PNSIPCF), published in December 2011, and which represents the possibility of a commitment between the Brazilian state and the health of these populations.

The National Policy treats as a rural population peoples and communities whose ways of life and social reproduction are related to the countryside, the forest, aquatic environments, agriculture and extractivism, such as: family farmers; settled and encamped rural workers; residents of quilombos (former slave communities); populations of extractive reserves; and other traditional communities [2].

According to [5], neglected diseases accounted for $12 \%$ of the global disease burden, but only $1.3 \%$ of new drugs that were created in the period 1974-2004, of a total of 1,556 discoveries, related to such diseases. In terms of research spending, overall spending on health was US\$160 billion on 2005, of which only US\$3.2 billion was for the treatment of diseases of vulnerable populations.

Fourteen of the 17NTDs listed by the World Health Organization (WHO) are found in Brazil. The improved health conditions of the population have not reduced the incidence of communicable diseases, which persist, especially those considered neglected, as they are not economically attractive for the development of drugs by the major pharmaceutical industries.

According to the Applied Research Institute, the relationship between poverty and inequality, as well as other social indicators, affects health and allows the analysis and inequality, as well as other social indicators, affects health and allows the analysis and a product and producer of social and environmental differentiations, with significant repercussions for the health of population groups [6].

More than 24 million people live in 772 municipalities across the Amazon Region which is 5 million $\mathrm{km}^{2}$ in size and represents $59 \%$ of the Brazilian landmass. This population includes more than 170 indigenous peoples, mixed race and indigenous riverside populations quilombo residents and recent immigrants from various parts of the country. Much of the population is concentrated in urban areas, but many live in rural areas. There is little knowledge about these groups, especially in terms of their health and environmental sanitation and the neglected diseases that affect them $[7,8]$

The Legal Amazon covers an area of 510,981,200 million hectares, which is equivalent to $60 \%$ of the Brazilian landmass (Figure 1).

The Amazonian winter is an important regulating factor for biological processes, especially those related to infectious diseases. During this period rainfall predominates, with the increase of the volumes of rivers and floods in some cities and the occurrence of parasitic diseases related to the environment in which they are transmitted. Among the diseases of this period are: tuberculosis, leprosy, intestinal parasitoses, American tegumentary Leishmaniasis (ATL), visceral leishmaniasis (VL) and malaria (Table 1).

According to the [4] around 35 million Brazilians do not have access to treated water and half of the country has no sewage collection. Only $42 \%$ of sewage generated is treated, which explains the poor water quality of most rivers, reservoirs and bays. In this context, the universalization of treatment, water distribution, sewage collection and treatment services can result 
Citation: Corrêa LL, Figueira MCS, Pinheiro ASF. Neglected Tropical Diseases: social and environmental inequalities in the Brazilian Amazon. J Parasit Dis Diagn Ther. 2018;3(1):15-17. DOI: 10.4066/2591-7846.1000023

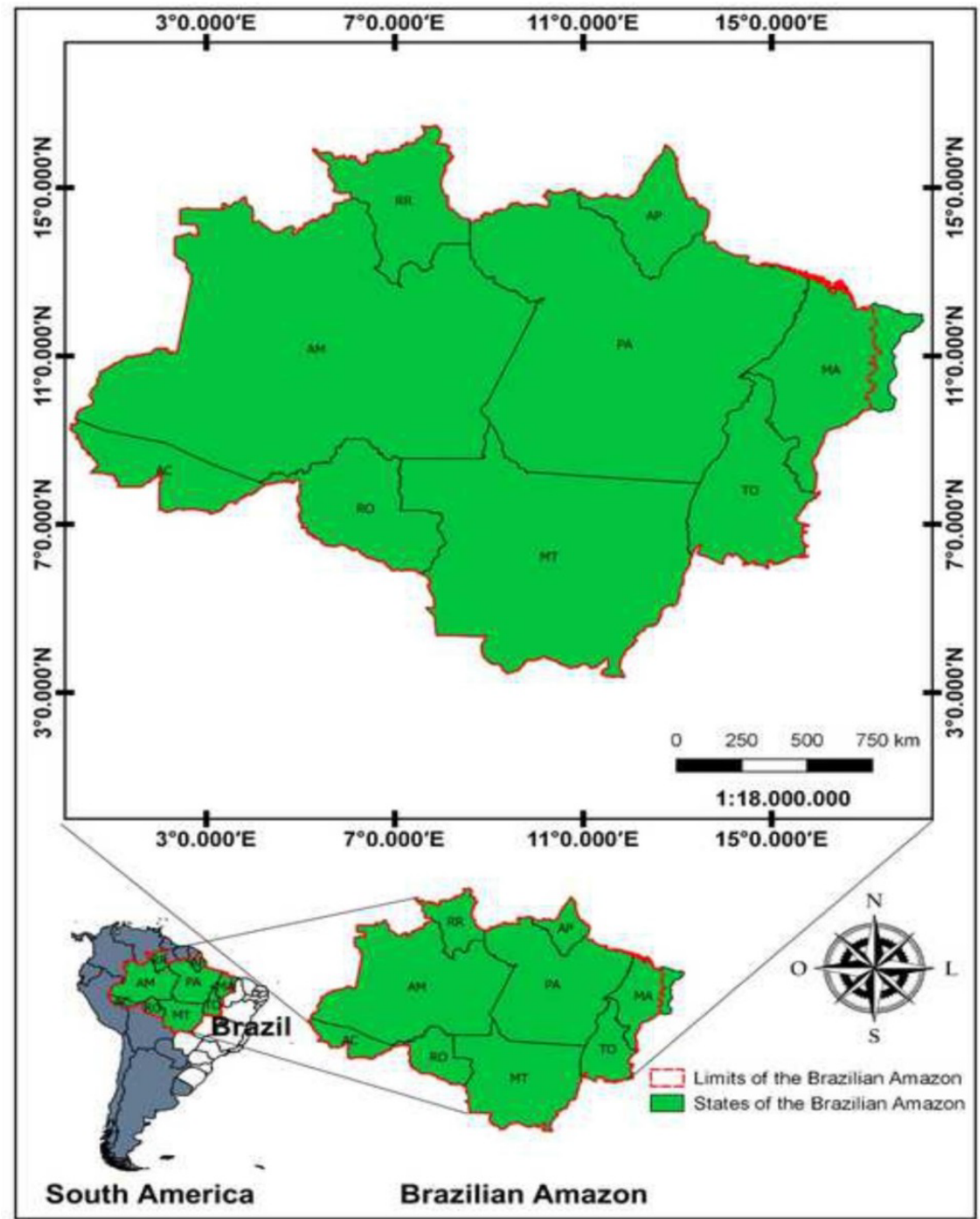

Figure 1. Map of South America, highlighting Brazil and the Brazilian Amazon.

Table 1. Indicators of the incidence of communicable diseases in the Brazilian Amazon (2009-2015) [6].

\begin{tabular}{|c|c|c|c|c|c|}
\hline $\begin{array}{c}\text { State/Federal } \\
\text { Unit-FU }\end{array}$ & $\begin{array}{l}\text { Rate of Incidence of } \\
\text { Tuberculosis (Per } \\
100,000 \text { inhab.) }\end{array}$ & $\begin{array}{l}\text { Coefficient of detection } \\
\text { of leprosy (Per 100,000 } \\
\text { inhab.) }\end{array}$ & $\begin{array}{c}\text { Rate of Incidence of } \\
\text { Visceral Leishmaniasis (Per } \\
100,000 \text { inhab.) }\end{array}$ & $\begin{array}{c}\text { Rate of Incidence of Cutaneous } \\
\text { Leishmaniasis (Per 100,000 } \\
\text { inhab.) }\end{array}$ & $\begin{array}{c}\text { Annual Parasite Index } \\
\text { (API) Malaria (Per } 1,000 \\
\text { inhab.) }\end{array}$ \\
\hline Amapá & 31.76 & 28.38 & - & 76.17 & 25.96 \\
\hline Acre & 44.26 & 33.67 & - & 128.78 & 39.76 \\
\hline Amazonas & 64.81 & 19.75 & 0.02 & 44.28 & 22.51 \\
\hline Pará & 48.21 & 51.77 & 3.91 & 41.34 & 16.16 \\
\hline Rondônia & 34.03 & 60.91 & 8.06 & 57.41 & 25.6 \\
\hline Roraima & 30.63 & 30.41 & 2.22 & 97.08 & 38.04 \\
\hline Mato Grosso & 36.37 & 88.48 & 1.86 & 91.08 & 0.86 \\
\hline Maranhão & 35.75 & 60.86 & 6.52 & 35.33 & 0.72 \\
\hline Tocantins & 13.95 & 77.37 & 30.26 & 39.92 & 0.08 \\
\hline
\end{tabular}

in positive economic and social effects on income, health, and in the markets of the Brazil of the future. Analysis of the information relating to the percentage of the population with access and sanitation deficits reveals the scale of the challenge in the Amazon region of Brazil [8,9].

The data show the conditions of the Amazonian population and the incompatibility between the natural wealth of the region and the poverty of its people, who lack access to several basic rights, such as sanitation, housing, health and well-being. One study [8] was based on an index that goes further than popular Human
Development Index (HDI), known as the Social Progress Index (SPI), which measures the quality of life of the residents of each locality in a more transparent manner. It was created to assess global social development and includes 50 additional indicators, such as health, housing, personal security, access to information, basic sanitation and sustainability.

The constitutional mandate guides the creation of public sanitation and sewage policies in Brazil. Articles 23, 196 and 225 of the Federal Constitution contain provisions that deal with sanitation, health services and environmental protection, 
while Articles 21, 25, 30 and 182 govern the competences of the federal entities (the Union, the states, the Distrito Federal (Federal District) and the municipal regions). This is explained by the federative pact, and the guarantee of the relative autonomy of the administrative spheres, although it is necessary to resort to infra-constitutional norms in order to develop policies.

Complying with the Law of Basic Sanitation while taking into account the local realities of most municipal regions reveals the great difficulties involved in achieving the objective of legislation. The situation is made worse by the requirement that the application of resources in sanitation and sewage systems should be preceded by planning at the municipal, state and federal levels. According to Decree No. 8,629 dated 12/30/2015, from December 2017 the release of the budgetary resources of the Union for sanitation and sewage works depends on the existence of a Basic Municipal Sanitation Plan, while the same legislation ties the validity of sanitation and sewage service contracts to the existence of municipal sanitation and sewage plans, considerably affecting the Brazilian Amazon.

Globally, Brazil is in the $46^{\text {th }}$ position in a ranking of 132 countries measured using the SPI. The Brazilian version of the index, with small adaptations from the global methodology, shows that the Brazilian Amazon has an SPI of 57.31, compared to a national average of 67.73 [8].

Due to the difficulty surrounding notifications these diseases, the information system has undergone modifications to meet the needs of health surveillance in the three spheres of government, providing strategies that aim to effectively monitor such illnesses, considering the country's biogeographic characteristics and its broad biological and socio-cultural Diversity [10].

Information about the behavior of a disease allows the identification of individual and collective problems in the health of a population, providing a basis for the analysis of the situation and support for the seeking of alternative measures, as well as assisting actions related to the health/disease process [10].
To this end, the Ministry of Health recommends that health education activities should be provided to all services that carry out actions that monitor and control neglected diseases, so that strategies of promotion and prevention are implemented.

\section{References}

1. http://bvsms.saude.gov.br/bvs/saudelegis/gm/2011/ prt2866_02_12_2011.html

2. Brasil Ministério da Saúde, Secretaria de Vigilância em Saúde, Saúde brasil 2013: uma análise da situação de saúde e das doenças transmissíveis relacionadas a pobreza. 2014.

3. www.ruralpovertyportal.org/country/home/tags/brazil

4. http://www.tratabrasil.org.br/datafiles/estudos/ beneficios-148 ecosocio/relatorio-completo.pdf

5. Medeiros R Na. Sombra do esquecimento. Revista do Conselho Federal de Medicina. 2014;5:56-70.

6. Garcia LP, Silva GDM. Doenças Transmissíveis e Situação Econômica no Brasil: Análise Espacial. Texto para Discussão $N^{\circ}$ 2263. Instituto de Pesquisa Econômica Aplicada; Brasília: Rio de Janeiro: Ipea. 2016.

7. Becker BK. Cenários de Curto Prazo para o Desenvolvimento da Amazônia. Cadernos IPPUR. 2000;14:53-86.

8. https://s3-sa-east-1.amazonaws.com/ipsx.tracersoft.com. br/documents/IpsAmazonia_2014_Final.pdf

9. Corrêa LL, Pinheiro ADSF. Dynamics of Parasitic diseases and the environmental and sanitation context in cities of the Brazilian Amazon. Journal of Parasitic Diseases: Diagnosis and Therapy. 2017;2.

10. Nascimento ES, Maia-Herzog M, Sabroza PCO. Acesso público da informação em saúde para as doenças negligenciadas no Brasil. RECIIS-R Eletr de Com Inf Inov Saúde 2012;6.

\section{*Correspondence to:}

Lincoln Lima Corrêa

Department of Parasitology

Institute of Water Science and Technology

Federal University of Western Pará, UFOPA, Brazil

E-mail: lincorre@gmail.com 